\title{
Being oneself and being self-conscious. Spinoza's concept of freedom
}

\section{Hynek Tippelt ${ }^{1}$}

Abstract: The aim of this study is to clarify Spinoza's concept of freedom and outline the meaning of this concept in Spinoza's philosophical system as a whole. First, I outline the position of the topic of freedom within the framework of Spinoza's philosophical teachings and its reception. Then I gradually turn to how Spinoza's topic of freedom appears in the context of ontology, ethics and political philosophy. Spinoza's philosophy is ontological - ethics and political philosophy are the application of his ontology. That is why I will start with the interpretation of its basic metaphysical notions - substance, attributes, and modes. In an ethical context, it is possible to speak of Spinozism of freedom with regard to the concept of so-called power of mind over affects, which will be the next center of interpretation. I will conclude with a summary of Spinoza's political-philosophical views on freedom.

Keywords: Baruch Spinoza, ontology, ethics, freedom.

\footnotetext{
${ }^{1}$ Filozofická fakulta Univerzity Jana Evangelisty Purkyně, Pasteurova 13, 400 96, Ústí nad Labem.
} tippelt@centrum.cz 


\section{Freedom in the context of philosophical work and its reception}

To determine the position of the topic of freedom within B. Spinoza's philosophical teaching and how it was accepted, we must take into account that Spinoza's philosophy is characterized by considerable cohesiveness. This is due to both methodological considerations and basic features of his metaphysical vision. The ambition to present a unified and complete philosophical system is clear and is consistent with his teaching, which can be summarized as "anything that exists is a modification of the only existing thing". Permanent consideration of the whole that is present in his philosophy, and which we can call its holistic nature, can seduce those who seek a fixed hierarchy of philosophical disciplines in a philosophical system, questions, and answers. In Spinoza's teaching, as in his ontology, everything is related to everything.

Devotion to the mathematical model of human knowledge binds Spinoza to the construction of an axiomatic system that demonstrates the rational organization of nature. ${ }^{2}$ In spite of the fact that in the spinozian world the center is everywhere and nowhere, some nodal points of Spinoza's interpretation can be identified. These include substance, mind, idea, affects and many others. In Spinoza's argumentation, the motif of freedom is constantly present, which forms an axis of those nodal concepts.

The theme of freedom is ubiquitous for Spinoza. His early work Short Treatise on God, Man, and His Well-Being ${ }^{3}$ ends with the chapter On true freedom, where he defines freedom as "a firm reality which our understanding acquires through direct union with God, so that it can bring forth ideas in itself, and effects outside itself, in complete harmony with its nature." (KV 26, 16) The last chapter of Metaphysical thoughts ${ }^{4}$ ends with the chapter Of the human mind. Spinoza argues that the mind has will (CM $2.12 \S 10)$, which is free, "for no thing has the power to destroy its essence" (CM 2.12, §11).

In Spinoza's most elaborate work Ethics, demonstrated in geometrical order ${ }^{5}$ we come across motifs of freedom for the first time in the introductory definitions of its first part:

"That thing is called free, which exists from the necessity of its own nature alone, and is determined to action by itself alone. That thing, on the other hand, is called necessary, or rather compelled, which by another is determined to existence and action in a fixed and prescribed manner." (E1D7)

The first part of Ethics is called Of God and there we can find an explanation of the substance structure, the only fully-existing thing that is unlimited and eternal. Only the all-encompassing substance is eternal, singularities are determined as modifications of its attributes in a network of all-pervasive causality. The fourth part of Spinoza's Ethics is called Of the Servitude of Humanity, or the Strength of the Emotions, however, seven final statements of this section deal with the basic aspects of the practical life of the liberated mind. It starts with the following notion:

\footnotetext{
2 Cottingham, John. 1988. "The Rationalists."

${ }^{3}$ de Spinoza, Benedictus. 1963. "Short Treatise of God, Man, \& His Well-Being."

${ }^{4}$ Spinoza, Baruch and Lee Rice. 1998. Principles of Cartesian Philosophy: With Metaphysical Thoughts and Lodewijk Meyer's Inaugural Dissertation: Hackett Publishing.
}

${ }^{5}$ Spinoza, B. 2007. "Ethica Ordine Geometrico Demonstrata [Ethics, Demonstrated in Geometrical Order]." Amsterdam: Jan Rieuwertsz. 
"A free man thinks of death least of all things, and his wisdom is a meditation of life, not of death" (E4P67),

and ends with

"The man who is guided by reason is more free in a state where he lives under a system of law than in solitude where [he] only obeys himself" (E4P73).

The thematization of freedom in the fifth part of Ethics is evident from its title Of the Power of the Intellect or the Liberty of Humanity. In the preface to this section, Spinoza states that he will speak of "the way to be followed to achieve freedom" and that he will show "what freedom of mind [or] happiness" is. In the final note to Ethics, Spinoza states that he discussed "everything [he] wanted to show concerning the mind's power over the affects and concerning its freedom" (E5P42Sch).

The topic of freedom is also at the forefront of Spinoza's political-philosophical writings. In the final chapter of the Theological-political treatise ${ }^{6}$ from 1670, titled On freedom of opinion and freedom of speech, with the subtitle "In a Free State every one is at liberty to think as he pleases and to say what he thinks" Spinoza assesses the quality of a state precisely with regard to freedom of expression:

"a government would be most harsh which deprived the individual of his freedom of saying and teaching what he thought; and would be moderate if such freedom were granted" (TTP 20.9)

Despite the outlined position, Spinoza's concept of freedom was not thematized nearly as much as his solution to the psychophysical problem or question of the materialistic nature of his metaphysics. The current revival of interest in Spinoza is most often related to the theory of knowledge, ideology or power. ${ }^{7}$

For instance, Jonathan Francis Bennett paid considerable attention to freedom in his study ${ }^{8}$ of Spinoza's Ethics. He was skeptical in regards to the coherence of Spinoza's system. Another example is Jon Wetlesen, who considered Spinoza's teaching to be the way to enlightenment. ${ }^{9}$

Some psychoanalysts also derive from the central, but confusing position of the freedom motive in Spinoza's philosophy in their attempts to interpret it in the sense of anal sadism, a structure characteristic of clinging to order and falling into chaos and the conflict of desire for freedom and power ${ }^{10}$.

\section{Ontological thematization of freedom}

Spinoza's metaphysics is based on the monistic concept of the only all-encompassing thing called God or substance: "Whatever is, is in God, and nothing can be or be conceived without God" (E1P15). Singularities as events constitute one, they are interrelated and these

\footnotetext{
${ }^{6}$ De Spinoza, Benedictus. 2001. Theological-Political Treatise: Hackett Publishing.

${ }^{7}$ E.g.: Cook, Thomas. "Adequate Understanding of Inadequate Ideas: Power and Paradox in Spinoza's Cognitive Therapy."

${ }^{8}$ Bennett, Jonathan. 1984. A Study of Spinoza's' Ethics': CUP Archive.

${ }^{9}$ Wetlesen, Jon. 1979. "The Sage and the Way: Spinoza's Ethics of Freedom."

${ }^{10}$ Compare: Scharfstein, Ben-Ami and Mortimer Ostow. 1952. "The Unconscious Sources of Spinoza's Philosophy." American Imago 9(3/4):221-37., or Feuer, Lewis S. 1968. "God, Guilt, and Logic: The Psychological Basis of the Ontological Argument." Inquiry 11(1-4):257-81.
} 
relationships are determined. Nature is the realm of necessity; the only thing that is free is nature itself:

"God is the efficient cause of all things that can fall under an unlimited intellect." (E1P16CorA) "Whatsoever is conditioned to exist and act, has been thus conditioned by God." (E1P28Dem)

"In Nature there is nothing contingent; all things have been caused by the necessity of the divine nature to exist and produce an effect in a certain way." (E1P29)

According to E1P7, a thing is free if it "exists solely by the necessity of its own nature, and of which the action is determined by itself alone." It is the cause of itself and "of which the essence involves existence or that of which nature is only conceivable as existent." (E1D1) Such thing Spinoza calls substance. By substance, he means "what is in itself and is conceived through itself" (E1D3). He argues that there only can be one such thing and that is God, "a being absolutely infinite - that is, a substance consisting in infinite attributes, of which each expresses eternal and infinite essentiality." (E1D6)

Spinoza does not attribute any sense of liberty to freedom. Nothing can be different than it is. This fundamental determinism is expressed in one of the first axioms of Ethics:

"From a given definite cause an effect necessarily follows; and, on the other hand, if no definite cause be granted, it is impossible that an effect can follow." (E1A3)

and in statement 28 of its first part:

"Every individual thing, or everything which is finite and has a conditioned existence, cannot exist or be conditioned to act, unless it be conditioned for existence and action by a cause other than itself, which also is finite, and has a conditioned existence; and likewise this cause cannot in its turn exist, or be conditioned to act, unless it be conditioned for existence and action by another cause, which also is finite, and has a conditioned existence, and so on to infinity." (E1P28)

Nor does God's freedom reside in unconditional freedom of will, but in self-determination and self-justification:

"God acts solely by the laws of his own nature, and is not constrained by anyone." (E1P17)

"God does not act according to freedom of the will." (E1P32Cor1)

God has no free will because he cannot decide what things will result from his nature:

"And although, when will or intellect be granted, an infinite number of results may follow, yet God cannot on that account be said to act from freedom of the will, any more than the infinite number of results from motion and rest would justify us in saying that motion and rest act by free will." (E1P32Cor2)

Everything else that exists necessarily results from God's nature. God is "the absolutely first cause" (E1P16Cor3) that specifies an infinite number of effects. The world that exists is the only one possible. "Things could not have been brought into being by God in any way or in any order different from that which has in fact been obtained" (E1P33Dem), because "Of everything whatsoever a cause or reason must be assigned, either for its existence, or for its non-existence" (E1P11 Second Proof).

Spinoza's concept of freedom is closely related to his solution to Descartes' psychophysical problem: How can the body influence the mind and mind influence the body when those things are of utterly different nature? Spinoza refuses to view the body and mind as two different substances and understands them as two attributes of a single existing substance: 
"...mind and body are one and the same thing, conceived first under the attribute of thought..." (E3P2Sch)

Freedom, then, cannot mean independence of mind from the body. The mental contents that constitute the mind are independent of the states of the body in the sense that they are two expressions of the same entity, and therefore cannot be the cause of one another:

"Body cannot determine mind to think, neither can mind determine body to motion or rest or any state different from these, if such there be." (E3P2)

"That, therefore, which determines the mind to thought is a mode 11 of thought, and not a mode of extension; that is, it is not body. ... the motion and rest of a body must arise from another body..." (E3P2Dem)

The unity of mind and body does not contradict the fact that they cannot influence each other since they share the same necessity, order, arrangement of context:

"The order and connection of ideas is the same as the order and connection of things. ... whatsoever can be perceived by the infinite intellect as constituting the essence of substance, belongs altogether only to one substance: consequently, substance thinking and substance extended are one and the same substance, comprehended now through one attribute, now through the other. So, also, a mode of extension and the idea of that mode are one and the same thing, though expressed in two ways." (E2P7)

Spinoza's concept of freedom involves recognizing the necessity of causal links between all individual states of substance. Such determinism precludes the idea of free will:

"In the mind there is no absolute or free will; but the mind is determined to wish this or that by a cause, which has also been determined by another cause, and this last by another cause, and so on to infinity." (E2P48)

"It is impossible, that man should not be a part of Nature, or that he should be capable of undergoing no changes, save such as can be understood through his nature only as their adequate cause." (E4P4)

True freedom, according to Spinoza, is not an escape from causality and an all-encompassing determination, but rather its fulfillment. Each of us is determined by the desire to stay in being. It is the ultimate root of our motivation, the ultimate cause of all our activities:

"Everything, in so far as it is in itself, endeavors to persist in its own being.." (E3P6)

Therefore, being free means not to seek anything but to preserve one's being. Free will is an illusion because if we are not determined by external things, we are determined by our desire to remain in being:

"... men think themselves free inasmuch as they are conscious of their volitions and desires, and never even dream, in their ignorance, of the causes which have disposed them so to wish and desire." (E1 App)

“...men are mistaken in thinking themselves free.” (E2P35Sch)

“... believes that of its own free will it desires milk, an angry child believes that it freely desires vengeance, a timid child believes that it freely desires to run away; further, a drunken man believes that he utters from the free decision of his mind words which, when he is sober, he

\footnotetext{
${ }^{11}$ Modus is Spinoza's expression for singularity. He defines it as "modifications of substance, or that which exists in, and is conceived through, something other than itself" (E1D5).
} 
would willingly have withheld: thus, too, a delirious man, a garrulous woman, a child, and others of like complexion... Experience teaches us no less clearly than reason, that men believe themselves to be free, simply because they are conscious of their actions, and unconscious of the causes whereby those actions are determined; and, further, it is plain that the dictates of the mind are but another name for the appetites, and therefore vary according to the varying state of the body." (E3P2Sch)

The idea of free will also go against Spinoza's rationalist methodology. He thinks of freedom, which chooses without reason among the different options, "not only as nugatory, but also as a great impediment to organized knowledge” (E1P33Sch2).

"Most writers on the emotions and on human conduct seem to be treating rather of matters outside nature than of natural phenomena following nature's general laws. They appear to conceive man to be situated in nature as a kingdom within a kingdom." (Introduction to the third part of Ethics)

However, according to Spinoza, "It is not in the nature of reason to regard things as contingent, but as necessary" (E2P44). In other words, "It is in the nature of reason to perceive things under a certain form of eternity" (E2P44Cor2). For these reasons

“...that those things which pertain to the subject of this science can be regarded with the same liberty of spirit we are accustomed to in mathematical things, I was inquiring into it, paying special attention to human beings, human action, trying carefully not to laugh, not to mourn, not even curse, but to understand them; and to that extent reflect upon human passions, such as love, hatred, anger, envy, glory, God's mercy, and the rest of the emotions of the mind not as vices of human nature, but as properties, I was contemplating, that they belong to us just like heat, cold, storm, and thunder belong to the nature of atmosphere... "12

\section{Ethics of liberation and its techniques}

The jewel of Western philosophy, free will, does not have a place in real philosophy according to Spinoza for both ontological and gnoseological reasons. Yet, as has already been pointed out, freedom is the backbone of all his teachings. It's not, however, something we should compete for in social and economic games. It is rather an inherent aspect of a base that can be lifted up by the forces of the mind, which we nevertheless always count on in our own way without being aware of it. With a certain conviction, it might be said that Spinoza values necessity more than he does freedom, but more valuable than both is liberation.

Liberation is the way we all undertake and is the purpose of all our activity. It is our innermost desire to stay in being that leads us to the goal of liberation. The freer we become, the more we can maintain our being; the freer we are, the more secure we are in it. In Ethics, where we can best follow Spinoza's philosophical system in action, freedom is the main theme of the final part called Of the Power of the Understanding, or of Human Freedom. Just from the title, it is clear that Spinoza treats the process of liberation as a matter of mind. In accordance with his teachings, however, simultaneously with the liberation of the mind, the corresponding processes must also take place in the attribute of propagation.

The power of mind consists in the power of reason that lies in the power to create ideas. Spinoza distinguishes different types of ideas. The most important difference is between adequate and

\footnotetext{
12 de Spinoza, Benedictus and Carl Hermann Bruder. 1843. Benedicti De Spinoza Opera Quae
} Supersunt Onmia, Vol. 1: typis et sumtibus Bernh. Tauchnitz jun., personal translation. 
inadequate ideas. While the mind is the cause of adequate ideas, the cause of inadequate ideas is something external. An inadequate idea is not necessarily false, rather it is not informative, it's misleading. An inadequate idea does not show its subject in the necessary causal connection with other ideas. Adequate knowledge, on the other hand, is knowledge based on the understanding of the principle of cause and effect. The power of reason, therefore, lies in the power of ideas of causal relationships.

The last cause of each effect in Spinoza's metaphysical system is God's essence. Knowing the essence of something according to Spinoza is equal to the knowledge of the closest cause. The highest degree of knowledge that Spinoza in Ethics calls intuitive "proceeds from an adequate idea of the absolute essence of certain attributes of God to the adequate knowledge of the essence of things" (E2P40Sch2). Liberating rational knowledge is, therefore, the knowledge of God as something that contains everything in itself, and what makes possible to understand anything else.

What exactly the power of mind mentioned in the title of the fifth part of Ethics is concerned with or what does it extend over? Spinoza states that it is the power of mind over affects. This statement may, however, be very confusing, as Spinoza realizes, and so most of the foreword to the fifth part is devoted to its explanation. The power of the mind cannot be represented as the supremacy of the "intellectual component" of the mind over its "affective area". Such a meaning of the power of mind over affects, which would lie in some victorious fight of reason against emotions, would be entirely foreign to Spinoza's theory. The power of mind over affects lies in the fact that mind may have an effect on or restrain affects, but not by replacing it with ideas - that would be impossible - but by helping to create affects that liberate us.

According to Spinoza, the human mind does not and cannot have absolute power over affects. Affectivity is an inherent part of our existence, so reason cannot "win" over it:

"An emotion can only be controlled or destroyed by another emotion contrary thereto, and with more power for controlling emotion.” (E4P7)

The power of the mind is based on the fact that affects are created by ideas, and therefore we can control our affects by what ideas we create. It has already been said that Spinoza favors ideas he calls adequate and that the supreme adequate idea is the idea of God. To make it clear why the idea of God has a liberating effect, it's time to stop at Spinoza's theory of affect:

"By emotion I mean the modifications of the body, whereby the active power of the said body is increased or diminished, aided or constrained, and also the ideas of such modifications." (E3D3)

Affect is a transition, which distinguishes it from the idea. It is affect that gives dynamics to the mental space. Affects impact both body and mind. It is the state of the body, the body mode, the state of mind, the idea (the object of which is a physical mode). It is a transition that takes place simultaneously in the body and the mind. Its quality is determined by the variation in the ability to do something. Affects such as envy or hate weaken us, while joyful affects like love reinforce us. Since the capacity of having affects is related to the possibility to change according to Spinoza, it is related to finality. God, the infinite substance, the causes of oneself and of all being, does not have affects.

Spinoza's term affect is sometimes translated as emotion. This is somewhat misleading. It should be noted that according to Spinoza affect may be rational or irrational, depending on whether it is shaped by rational or irrational ideas. Just as an idea can be characterized by the degree of its rationality, affect can similarly be characterized by it. One of the limitations of the axis according to which the rate or degree of rationality of affect can be judged is one of the 
overarching concepts of Spinoza's philosophy, amor Dei intellectualis, the rational love of God, the affect that is shaped by the highest intellectual concept.

For understanding the meaning of Spinoza's concept of liberation through the power of mind over affects it is crucial to distinguish between two types of affections - passive and active which are presented in definitions 1-3 of the third part of Ethics. The second definition introduces a distinction between activity and passivity:

"We act when anything takes place, either within us or externally to us, whereof we are the adequate cause; that is (by the foregoing definition) when through our nature something takes place within us or externally to us, which can through our nature alone be clearly and distinctly understood. On the other hand, I say that we are passive as regards something when that something takes place within us, or follows from our nature externally, we being only the partial cause."

The third definition distinguishes between active and passive affects:

"By emotion I mean the modifications of the body, whereby the active power of the said body is increased or diminished, aided or constrained, and also the ideas of such modifications. If we can be the adequate cause of any of these modifications, I then call the emotion an activity, otherwise I call it a passion, or state wherein the mind is passive."

According to Spinoza, there are three basic affects: desire, pleasure, and pain. In Ethics, Spinoza first talks about affects as if they were necessarily something passive:

"Thus we see, that the mind can undergo many changes, and can pass sometimes to a state of greater perfection, sometimes to a state of lesser perfection. These passive states of transition explain to us the emotions of pleasure and pain. By pleasure therefore in the following propositions I shall signify a passive state wherein the mind passes to a greater perfection. By pain I shall signify a passive state wherein the mind passes to a lesser perfection." (E3P11Sch)

In the conclusion of the same section of Ethics, he denies this principle:

"Besides pleasure and desire, which are passivities or passions, there are other emotions derived from pleasure and desire, which are attributable to us in so far as we are active." (E3P58)

Thus, we distinguish between passive desire, pleasure and pain, and active desire and pleasure. An active counterpart of pain does not occur in Spinoza's texts. So what is the major difference between passive and active affects? It has already been said that affects are shaped by ideas. Thus, defining the difference between active and passive affects, Spinoza relies on the difference between adequate and inadequate ideas:

“... emotion or passion of the soul is a confused idea. For we have shown that the mind is only passive, in so far as it has inadequate or confused ideas." (General definitions of emotions from the conclusion of the third book of Ethics, an explanation for this definition).

The power of mind over affects lies, therefore, in replacing inadequate ideas with adequate ones. The substitution of passive affects with active ones in Spinoza's teachings is made possible by the fact that activity and passivity are not entirely different concepts, but rather different interpretation of it or, more precisely, a different interpretation of its origin. In this sense, Spinoza states in E4P59:

"To all the actions, whereto we are determined by emotion wherein the mind is passive; we can be determined without emotion by reason." 
The change of determination, mentioned in this statement, is what is going to guide to achieving what we want in life according to Spinoza's ethics. However, Spinoza does not provide us with rules of how to behave and how to liberate oneself in the context of social or economic relationships. Spinoza's ethics is not a way of life or behavior - it is a way of thinking:

"Than this remedy for the emotions (to return to the point from which I started), which consists in a true knowledge thereof, nothing more excellent, being within our power, can be devised. For the mind has no other power save that of thinking and of forming adequate ideas." (E5P4Sch)

In the fifth part, Spinoza presents several techniques of mitigating affects and coping with them, as well as how to transform passive affects into active. Jon Wetlesen in his detailed study of Spinoza's teachings about freedom ${ }^{13}$ offers to divide these remedies, as Spinoza calls them, into two types of so-called liberation strategies: gradual and instantaneous. The gradual strategies are defined by Wetlesen as based on values and norms of reason and on the principal law of motivation, which says, that affect can be overcome only by opposite and stronger affect. ${ }^{14}$ Wetlesen, who is sympathetic to Buddhism, appreciates the plurality of thought-based liberation techniques that Spinoza offers. According to Wetlesen Spinoza's way to freedom is a kind of "middle way", which integrates gradual and instantaneous strategies and avoids all one-sidedness. ${ }^{15}$ While gradual liberation strategies are aimed at changing the degree of pleasurableness of affect, the instantaneous strategy changes our state completely. Gradual strategies are oriented toward standards and improvement. By contrast, the instantaneous strategy transcends all norms and does not allow them to be further refined.

Gradual strategies are based on the understanding of the relationship between feelings and ideas, and on the awareness of the context within the mind instead of the relationship of inner states to external subjects:

"If we remove a disturbance of the spirit, or emotion, from the thought of an external cause, and unite it to other thoughts, then will the love or hatred towards that external cause, and also the vacillations of spirit which arise from these emotions, be destroyed." (E5P2)

"An emotion towards a thing, which we conceive simply, and not as necessary, or as contingent, or as possible, is, other conditions being equal, greater than any other emotion." (E5P5)

"The mind has greater power over the emotions and is less subject thereto, in so far as it understands all things as necessary." (E5P6)

Gradually, we liberate ourselves by correcting our thinking about the world and the functioning of the mind, so we mitigate the confusion of our affects and their dependence on the notions of external events.

Wetlesen's instantaneous strategy lies in the possibility of completely changing one's state by radically transforming the view of the world. This strategy is based on the realization that our every state is related to the overall state of the universe and to every thing in particular, and in this sense expresses God's activity. It is actually an adaptation, recall of the basic teaching of Spinoza that everything is contained in God. This knowledge creates the state of the most

\footnotetext{
${ }^{13}$ Wetlesen, Jon. 1979. "The Sage and the Way: Spinoza's Ethics of Freedom."

$14 \mathrm{lbid}$.

15 Ibid.
} 
delightful and most active affair of the amor Dei intellectualis, the rational love of God. Among the claims that belong to Spinoza's "remedy", Wetlesen implies an instantaneous strategy E5P3:

"An emotion, which is a passion, ceases to be a passion, as soon as we form a clear and distinct idea thereof."

If we realize what affect really is and how it depends on God, we see that this affect is not passive, but is necessarily created by God. This awareness opens the way for a conscious identification with God. God as the cause of oneself is free, so in finding our unity with him we also find our freedom.

Jonathan Bennett ${ }^{16}$ distinguishes three techniques in the overall strategy of Spinoza that, according to his interpretation, can be used to resist the affects that deprive us of freedom:

- Reflection on determinism

- separation and connection

- transformation of passions into active affects.

According to Bennett's work, the transformation of passive affects into active lies at the heart of Spinoza's approach. However, Bennett considers this technique to be incompatible with Spinoza's definitions of active and passive affects. He claims that the difference between passive and active affairs lies in their causal history. These causes - Bennett argues - cannot change over time. Therefore, if affect is passive, it cannot change into active affect.

This paradox is striking in Spinoza's teaching and is related to what I would call its mystical nature. Spinoza's philosophy is illuminating and leads to a change of thought. The sudden strategy does not work according to Wetlesen's interpretation as a tool for changing our state from passive to active, from unfree to free, etc. - but paradoxically shows that no changes are needed. If we view this from the point of eternity, our states are not passive, but active, and their object is not us as modes but the substance itself. The sudden strategy thus reveals that freedom is something we always have without knowing it.

E5P3 can be called Spinoza's royal liberation technique. It describes the change that occurs when we see that all states are active because they are the states of a single substance that is determined by itself. The mind that recognizes these truths has a state of rational love for God. This love is a joy rooted in reality as it forms a whole of intertwined things. It is total satisfaction because the awareness of the mind in this state is also the highest activity because its source is the very essence of the mind - its unity with God.

Freedom as another aspect of the state of existence, which Spinoza also described as a rational love for God, is a possibility common to all things. Yet only a few people manage to achieve it because it requires not only considerable cultivation of thought but also - as Sigmund Freud mentioned - "unusual integrity, generosity, and modesty"17.

\section{$4 \quad$ Freedom in society and within the state}

According to Spinoza, man naturally longs for civil status (TP6.1). He enters the state to strengthen and protect his freedom (E4P73). He gives up part of his power not to be subject to

\footnotetext{
16 Bennett, Jonathan. 1984. A Study of Spinoza's' Ethics': CUP Archive.

17 Jammer, Max. 2000. "Einstein and Religion: Physics and Theology." AAPT.
} 
the unlimited application of the natural interests of other people. The freedom of the individual in the state comes first, the same way it is in the state of nature:

"No, the object of government is not to change men from rational beings into beasts or puppets, but to enable them to develop their minds and bodies in security, and to employ their reason unshackled; neither showing hatred, anger, or deceit, nor watched with the eyes of jealousy and injustice. In fact, the true aim of government is liberty."

The state of nature in its own way persists in the political one because the individual still retains his natural rights (TP 3.3). It is worthwhile, however, to be obedient, although it is not reasonable to obey blindly (TP3.6). However, one cannot give up his freedom to decide what is good and bad for him because no one can give up his efforts to stay in being (TTP20.8). Under normal circumstances, the citizen is obedient, because the will of the state is the will of everyone within that state, including the will of individual citizen (TP3.5). But if the state is not organized on the basis of reason and freedom there is suppressed, the citizen no longer has to obey, because the state does not fulfill its function (TP4.4).

Spinoza seeks to cleanse society from the pernicious influence religious authorities have on it if they are allowed to control people's opinions. In the preface to Theological-Political Treatise, he argues that:

"The mob has no ruler more potent than superstition, and is easily led, on the plea of religion, at one moment to adore its kings as gods, and anon to execrate and abjure them as humanity's common bane. ... But if, in despotic statecraft, the supreme and essential mystery be to hoodwink the subjects, and to mask the fear, which keeps them clown, with the specious garb of religion, so that men may fight as bravely for slavery as for safety, and count it not shame but highest honour to risk their blood and their lives for the vainglory of a tyrant; yet in a free state no more mischievous expedient could be planned or attempted." (TTP preface)

Superstition only controls us when we fear something. It merely is an inadequate knowledge that recedes, as adequate knowledge extends. That is why the freedom to philosophize is critical for society. The defence of freedom to philosophize was one of the main goals of the Theological-Political Treatise and based on that Spinoza came up with a rather original proposal regarding the separation of spiritual and secular, as well as private and public affairs. On the one hand, Spinoza separates reason from faith, on the other hand, entrusts public manifestations of religion to the state (TTP 19). Spinoza obviously does not have the freedom of religious expression in mind as much as freedom of philosophizing. A certain minimal level of religion necessary for unity and peace in society should, in his opinion, be ensured by the state. While freedom of religion is guaranteed to citizens, it is limited to private rituals and beliefs.

Freedom of thought and expression must be secured by the state. It is not a threat to it, on the contrary, it strengthens security and stability within the state, because the freer the man is, the more reasonable he becomes (TP 2.7). A free man does not violate the laws because he values peace (E4P73).

Freedom must be limited in society (TP 1.3, TP 4.6), but the state can only use violence to ensure peace and order. Spinoza emphasizes that morality is not the major priority for the state. He also warns against ideological manipulation caused by usurpation of power:

"the judgment can be biassed in many ways, and to an almost incredible degree, so that while exempt from direct external control it may be so dependent on another man's words, that it may fitly be said to be ruled by him". (TTP 20.4) 
The best and most powerful state is based on reason and allows maximum freedom (TP 3.7). In order to protect freedom within the state, Spinoza advises not to keep a professional army (TP7.22). In a free state it is not necessary because the most honest people are a part of it, and they are not afraid of death: "... his mind is not wrung with remorse for any disgraceful deed: he holds that death in a good cause is no punishment, but an honour, and that death for freedom is glory."

The purpose of all institutions is to bring in the rationality that people lack. In a society in which everyone would live under the direction of reason, no political authority would be needed. The ideal form of the state must, therefore, be judged according to the reasonableness of the government. However, one cannot hope for an enlightened ruler or people (TP 1.5).

The best state will allow consistency in spiritually oriented life (TP5.5). Such a state can only be governed by free people because only those enjoy life (TP 5.6). Freedom in the state, therefore, depends on how many liberated people are involved in its administration.

Peace does not lay in the absence of war, but in the harmony of hearts (TP6.4), therefore, democracy is better than the monarchy. The advantage of the monarchy is that it will keep the state mostly stable (TP6.4), but the risk that it will fall into disarray is, of course, great (TP6.8). That is why Spinoza favors constitutional monarchy over the absolute monarchy. Some disadvantages of the monarchy may be elevated by the aristocratic system, but democracy seems to be the ideal form of government. Political Treatise in which Spinoza devotes his attention to the ideal government is unfortunately not finished, but the logic of his thinking seems clear: democracy is the highest form of government because the power of a democratic state is shaped only by the power of the people. ${ }^{18}$ The smaller is the difference between the power and the will of the state and the power and will of the people, the freer the state is and the better it functions. One can only speculate what Spinoza's opinion on direct democracy was, but the radicalness of his approach suggests he viewed it as positive.

In regard to the rules of everyday life, Spinoza was neither a libertine nor a rigid moralist. In order to avoid unnecessary conflicts, he recommended to adapt to normal standards (see: E4Ap15 or TIE §17), however, he saw no benefit in self-restraint:

"Assuredly nothing forbids man to enjoy himself, save grim and gloomy superstition. For why is it more lawful to satiate one's hunger and thirst than to drive away one's melancholy? ... Therefore, to make use of what comes in our way, and to enjoy it as much as possible (not to the point of satiety, for that would not be enjoyment) is the part of a wise man." (E4P45Sch)

Feminist philosopher Alexandre Matheron ${ }^{19}$ estimates that since Spinoza was tolerant in other issues of everyday life and living, he would also have a mild opinion on issues of sexual freedom. Matheron writes: "It is for each of us to judge to what extent and in what way it is good to make use of sexuality. The only condition, we have seen, is that it become neither obsessional nor conflictual, but we have seen also that it is less likely to become so the more reason develops: from a certain threshold all danger would be eliminated. Understand, and do what you will: here as elsewhere, this is the sole norm." 20

\footnotetext{
${ }^{18}$ Compare: Negri, Antonio. 2000. The Savage Anomaly: The Power of Spinoza's Metaphysics and Politics: $U$ of Minnesota Press.

${ }^{19}$ Gatens, Moira. 2009. Feminist Interpretations of Benedict Spinoza: Penn State Press.

20 Ibid.
} 


\section{Conclusion}

The central concept of Spinoza's metaphysics is undoubtedly substance, God. If we look for the central concept of Spinoza's philosophy, it could be a notion of freedom. In addition to the motives of intellectual love for God, eternity and eternal necessity, the effort to stay in being and the endless interdependence of all things, freedom is one of the pillars of his thinking. Freedom in the sense of self-propensity is a fundamental feature of substance. It is the goal of our quest for the highest good. It is also the basic value to be cared for by the state. Given that it points to the goal and the meaning of all life's effort, it can be called the axis of philosophy. In spite of this significance, the issue of freedom in the Spinoza's exploration was rather overlooked.

The reason for this neglect could be Spinoza's strong denial of freedom of will. The impossibility of free will clearly results from his determinism. We are incorporated into an endless sequence of causes and consequences that could not be created in a different order. According to Spinoza, those who believe in free will are dreamers, caught up in unreasonable affects. In spite of this, it is possible to speak of the liberation, in the sense of exercising the power of reason over affects, mitigating undesirable affects and gradually awakening from the illusion of the world of random events and free decisions. The exemption in this regard lies in inspecting the necessity of things.

Spinoza describes the process of liberation as the transition from passive affects to active. This transition is due to adequate knowledge because while our adequate ideas create active affects, our passive affects are shaped by our inadequate ideas. The possibility of liberation, therefore, arises from the constitutive relationship of our ideas to our affects. The way we think about our thoughts shapes the path we take. Liberation is not a matter of right action, but a change in how we look at things around us. The royal journey to freedom is the realization of the unity of self and God that creates the affect of the intellectual love of God and opens a perspective that we are not a passive component of a higher entity but an active co-creator of everything.

Because we enter the civil state in order to protect our freedom, freedom becomes the state's objective as well. That is why the citizen is not obligated to obey, if the state is not organized on the basis of reason, does not fulfill its function and freedom is suppressed there. The freedom to philosophizing is at the heart of our freedom because liberation is achieved by changing our view of the world, or by different interpretations of our affects. The greatest social danger of freedom is, therefore, the detrimental influence of religious authorities if they are allowed to control people's opinions. Freedom of thought and freedom of expression are fundamental rights and key values. According to Spinoza, the best state is the one that is the most liberal. Such a state is at the same time the most powerful since the free citizens are the most obedient, the most honest and defend their rights. A state with maximum freedom is the most intelligent because its unity relies on free people who enjoy life and value peace. The smaller is the difference between the power and the will of the state, and the power and will of the people, the freer is the state and, therefore, it seems that the ideal form of government would be a direct democracy in accordance with the Spinoza's way of thinking. 


\section{List of abbreviations}

\section{Works of Spinoza}

CM Metaphysical Thoughts (Cogitata Metaphysica) (CM 1.2 is Part 1, Chapter 2)

E Ethics (Ethica) (followed by numeral for part and internal references)

KV Short Treatise (Korte Verhandeling) (KV 1.2 is Chapter 1, Paragraph 2)

TIE Treatise on the Emendation of Intellect (Tractatus de intellectus Emendatione) (followed by numeral for paragraph)

TP Political Treatise (Tractatus Politicus) (TP1.2 is Chapter 1, Paragraph 2)

TTP Theological-Political Treatise (Tractatus Theologico-Politicus) (TTP 1.2 is is Chapter 1, Paragraph 2)

\section{Internal references}

$\begin{array}{ll}\text { A } & \text { Axiom } \\ \text { Cor } & \text { Corollary } \\ \text { Def } & \text { Definition } \\ \text { Dem } & \text { Demonstration } \\ \text { P } & \text { Proposition } \\ \text { Pr } & \text { Preface } \\ \text { Sch } & \text { Scholium }\end{array}$

\section{References}

Bennett, Jonathan. 1984. A Study of Spinoza's' Ethics': CUP Archive.

Cook, Thomas. "Adequate Understanding of Inadequate Ideas: Power and Paradox in Spinoza's Cognitive Therapy."

Cottingham, John. 1988. "The Rationalists."

de Spinoza, Benedictus and Carl Hermann Bruder. 1843. Benedicti De Spinoza Opera Quae Supersunt Onmia, Vol. 1: typis et sumtibus Bernh. Tauchnitz jun.

de Spinoza, Benedictus. 1963. "Short Treatise of God, Man, \& His Well-Being."

De Spinoza, Benedictus. 2001. Theological-Political Treatise: Hackett Publishing.

Feuer, Lewis S. 1968. "God, Guilt, and Logic: The Psychological Basis of the Ontological Argument." Inquiry 11(1-4):257-81.

Gatens, Moira. 2009. Feminist Interpretations of Benedict Spinoza: Penn State Press.

Jammer, Max. 2000. "Einstein and Religion: Physics and Theology." AAPT.

Negri, Antonio. 2000. The Savage Anomaly: The Power of Spinoza's Metaphysics and Politics: U of Minnesota Press.

Scharfstein, Ben-Ami and Mortimer Ostow. 1952. "The Unconscious Sources of Spinoza's Philosophy." American Imago 9(3/4):221-37. 
Spinoza, B. 2007. "Ethica Ordine Geometrico Demonstrata [Ethics, Demonstrated in Geometrical Order]." Amsterdam: Jan Rieuwertsz.

Spinoza, Baruch and Lee Rice. 1998. Principles of Cartesian Philosophy: With Metaphysical Thoughts and Lodewijk Meyer's Inaugural Dissertation: Hackett Publishing.

Wetlesen, Jon. 1979. "The Sage and the Way: Spinoza's Ethics of Freedom." 